\title{
SUMMER PRACTICUM PARTNERSHIP: IMPACT ON EFFICACY OF PRESERVICE TEACHERS
}

\author{
Jim Mostofo, Grand Canyon University
}

\begin{abstract}
This paper describes a partnership between a college of education at a Christian university in the southwest U.S. and a local high school where preservice teachers completed their practicum (field experience) during summer school. The benefits to and efficacy of the preservice teachers were examined using a qualitative postprogram survey. The results indicated that the authentic teaching experience provided the main benefit of the partnership and had the greatest impact on teacher efficacy. The preservice teachers also cited the experience of working with mentor teachers and connecting with high school students as impacting their confidence, and their efficacy was affected by the opportunity to observe their mentor teachers in the field.

Keywords: practicum/field-experience, preservice teachers, school partnerships, efficacy

\section{INTRODUCTION}

Sixty-two percent of new teachers report feeling underprepared for the realities they face in the classroom (Levine, 2006). Although the research is not clear as to what specific factors contribute to making teacher education programs more effective, there is strong evidence that they play a significant role in the knowledge and skill level of future teachers (NCATE, 2014). Providing a highquality training program that focuses on preparing preservice teachers to independently meet the needs of all the students is essential for schools to be successful (Duncan-Andrade, 2011) because quality teaching is a major contributor to student learning (Darling-Hammond, 2006, 2007, 2009; Darling-Hammond, Jaquith, \& Hamilton, 2012). Teaching is complex work, yet some preservice teachers presume it to be easy (Grossman et al., 2009). In fact, many preservice teachers believe that teaching is mostly common sense and professional study is not needed (Ball \& Cohen, 1999; Kennedy, 1999; Munby, Russell, \& Martin, 2001).

The challenge for teacher education is to provide preservice teachers opportunities to develop habits of continued professional learning (Chassels \& Melville, 2009; Ganesh \& Matteson, 2010; Hiebert,

Morris, Berk, \& Jansen, 2007) that include critical reflective thinking during practicum experiences (McDonald \& Kahn, 2014). Therefore, providing opportunities to learn under careful coaching by experts in low-risk settings is critical for novice teachers to begin learning their practice (Schön, 1987). Exposure to multiple learning experiences and a considerable amount of practice with support from mentors and their peers can have a great value for preservice teachers (Bowman \& McCormick, 2000; Chassels \& Melville, 2009; Morris, Hiebert, \& Spitzer, 2009; Tobin, Roth \& Zimmerman, 2001). Teacher education programs need to be designed to help preservice teachers develop the ability to learn from their teaching and enable them to grow beyond their university experience (DarlingHammond \& Hammerness, 2005).

This study examined the impact of a summer practicum partnership (field experience) for preservice teachers at a local high school. I am an associate professor in the college of education at a private Christian university in the southwestern United States, and I served as the director of this program. The college of education in which I teach has over 1,000 undergraduate preservice teachers on campus. In addition to my directorship,
\end{abstract}


I also teach secondary methods courses (classes on the methodology of teaching for future high school teachers) and classroom engagement and management courses. The local high school in which the practicum is housed is part of a large, inner-city district located near the university. The school has over 2,500 students: $77 \%$ Hispanic, $7 \%$ African-American, 7\% Asian/Pacific Islander, 6\% White, and 2\% American Indian. Eighty-three percent of the students receive free or reduced lunch.

In this paper I describe a qualitative investigation of 30 undergraduate preservice teachers who participated in this summer practicum partnership. This study sought to answer the following two questions:

- What were the benefits of this summer practicum partnership for the preservice teachers?

- How did this experience impact the efficacy of the preservice teachers?

The immediate importance of this paper is to evaluate this partnership for the college of education, which will focus on the benefits and efficacy for the preservice teachers who participated in this program. The broader impact will be found in the possibility of informing teacher educators and colleges of education about this summer practicum model and encouraging further research into similar summer practicum partnerships and their impact on future teacher efficacy.

\section{LITERATURE REVIEW}

\section{School and University Partnerships}

There is strong evidence to suggest that reallife experience is essential for future teachers, and partnerships with local schools might be one key factor in this endeavor. For teacher education programs to "flourish," partnerships between the local schools and university are essential (Freeman, 2009-2010, p. 15). Some research indicates that developing stronger relationships with schools is a distinguishing factor of exemplary teacher education programs (Darling-Hammond, 2006) and that having well-planned practicums not only benefit the preservice teacher but also the practicum school's classroom teacher and students (Freeman, 2009-2010). Hardman (2009) advocated for a direct link between university courses and practicums or field experiences. One key aspect of school and university partnerships is the amount of collaboration focused on aligned goals (AmreinBeardsley \& Barnett, 2012; Butcher, Bezzina, \& Moran, 2011). Darling-Hammond (2006) added that preservice teachers who are taking coursework alongside practicums will begin to "see and understand both the theory and practice differently" (p. 307).

Creating successful school partnerships involves sitting "side-by-side in the construction of partnership goals and objectives" (AmreinBeardsley \& Barnett, 2012, p. 107). Teacher education programs should strive to "venture out further and further from the university and engage ever more closely with schools in a mutual transformation agenda" (Darling-Hammond, 2006, p. 302). Partnerships with local schools allow colleges of education to meet the needs of local schools and improve communication for meeting school goals (Freeman, 2009-2010).

There is evidence that stronger and sustained partnerships between teacher education programs and local schools are one viable solution to improving the gap between the university classroom and real teaching experience (Darling-Hammond, 2006; Louden \& Rohl, 2006). School partnerships have the possibility of bridging some of the theorypractice gap and, at the same time, allow teacher education programs and locals schools to share knowledge (Stephens \& Boldt, 2004). However, some contend that sustaining partnerships with consistent collaboration can be a struggle due to the lack of understanding the two cultures have for each other or different expectations between teacher educators and the local schools (Allen \& Turner, 2012; Sachs, 1999).

\section{Outreach and Engagement}

Byrne (1998) defined the difference between outreach and engagement. Outreach is a university reaching out to the people and organizations that they serve as a form of public service, while engagement involves a partnership or exchange between a university and its constituents. Lynton (2016) focused on the importance of outreach for a university because it provides a bridge between the theory and practice that benefit the teaching and learning process. He added that universities are "uniquely qualified to provide outreach that 
makes direct use of the professional expertise of their faculty" (Lynton, 2016). Engagement is mutually beneficial to the university and society (in this case the college of education and the local high school). Schön (1995) referred to new scholarship as a way of engaging that focuses on collaboration and dedication to learning with an emphasis on the community and mutual concern. After outreach, the new insights gained should be shared among colleagues (Lynton, 2016). The scholarship of application should allow professors to become reflective practitioners who move from theory to practice and then back again (Boyer, 1997). Colleges and universities should become more actively engaged in their local schools and view their surrounding $\mathrm{K}-12$ schools as partners as the scholarship of engagement allows universities to connect their resources to help society (Boyer, 1997).

\section{Efficacy for Preservice Teachers}

Investigating teacher self-efficacy is crucial in teacher education programs because teachers with a high level of teacher self-efficacy have shown more resilience in their teaching and are more likely try harder to help all of their students learn (Pendergast, Garvis \& Keogh, 2011). Bandura (1997) defined teacher efficacy as "beliefs in one's capabilities to organize and execute the courses of action required to produce given attainments" ( $p$. 3). Efficacy is vital in teaching because it impacts behavior, motivation, success, and failure (Bandura, 1982, 1986, 1993, 1997). Ashton (1984) added to Bandura's work by further defining efficacy as the extent that teachers feel capable of teaching the material and the extent that their students can learn the material. Teacher efficacy directly impacts teacher behavior (Henson, 2001a), student achievement (Anderson, Green, \& Loewen, 1988; Moore \& Esselman, 1992; Ross, 1992), and teacher motivation (Midgley, Feldlaufer, \& Eccles, 1989).

Teacher efficacy is related to teacher effectiveness and has been shown to positively influence students in not only achievement but also in their attitude (Oh, 2011). Consequently, some have begun to study the source of efficacy for preservice teachers and how it might be influenced. Whereas experienced teachers have many mastery experiences from which to draw, preservice teachers typically do not have multiple teaching experiences before their student-teaching that impact their efficacy (Chan, 2008; TschannenMoran \& Hoy, 2007). Oh (2011) found that preservice teachers' "motivation and capabilities were one of the important sources to improve their teaching efficacy" (p. 239). The development of preservice teachers' efficacy should be at least partially attributed to the capabilities they acquire primarily through practice teaching, observations, and dealing with daily matters (Yeung \& Watkins, 2000). Teacher education programs play a major role in the development of the efficacy of preservice teachers because they provide instructional opportunities, practice-teaching experiences, and feedback (Capa Aydin \& Loadman, 2006; Gordon \& Debus, 2002; Hoy \& Spero, 2005; Lin, Gorrell, $\&$ Taylor 2002).

The research on self-efficacy for preservice teachers during practicums is not extensive (Caprano, Caprano, \& Helfedt, 2010). Research indicates that mastery experiences are considered the most powerful due to the direct evidence of a preservice teacher being successful at teaching (Bandura, 1997; Mulholland \& Wallace, 2001). Successful experiences in teaching lead to higher teacher self-efficacy for preservice teachers, while unsuccessful teaching experiences can lower teacher self-efficacy (Pendergast, Garvis, \& Keogh, 2011). Self-efficacy tends to increase during teacher education programs according to some research (Hoy \& Spero, 2005; Wenner, 2001; Woolfolk \& Hoy, 1990), but it tends to diminish after graduation until the end of the first year of teaching (Hoy, 2000; Moseley, Reinke, \& Bookout, 2003). Webb, Ashton, Kelly, and Kamali (1996) argued that preservice teachers' self-efficacy varies during the course of a teacher education program due to the many fluctuations of positive or negative learning experiences. The schools where preservice teachers are placed for their practicums can significantly impact this self-efficacy development (Flores, 2015). However, some studies report that not all preservice teachers show an increase in selfefficacy. For example, Gencer and Cakiroglu (2007) found that taking additional teacher education classes did not improve preservice teacher's selfefficacy.

Wagler (2011) found no positive change in preservice teacher's self-efficacy based on the vicarious experience of observing their mentor 
teachers. Some research indicates that significant increases in self-efficacy are not evident for preservice teachers despite participating in practice-teaching during their practicum experiences (Gencer \& Cakiroglu, 2007). In fact, if beliefs are too high, some preservice teachers could encounter a "reality shock" when faced with a difficult experience (Pendergast et al., 2011, p. 55). Other research counters this argument. Yilmaz and Cavas (2008) argued that practice-teaching during practicums is the most important influence for the self-efficacy of preservice teachers. However, not all mastery teaching experiences for preservice teachers impact their efficacy because the feedback they receive is filtered through their own personal thoughts (Pendergast et al., 2011).

\section{Theoretical Framework}

Boyer (1990) argued that there are four forms of scholarship that should be recognized as legitimate by the academic system: discovery, integration, application, and teaching (see Figure 1). The theoretical framework for this study incorporated Boyer's scholarship of application as it involves the use of knowledge to solve problems. As Boyer stated, the scholarship of application is "the scholarship of engagement; seeking to close the gap between values in the academy and the needs of the larger world" (Boyer, 1997, p. 2). Knowledge is typically applied to the solution of societal needs in the scholarship of application (McGrath, 2006).

In this study, the gap was two-fold. The local high school was seeking more assistance for their teachers and students to continue to increase their achievement. Therefore, they sought assistance from the college of education for the preservice teachers to help fill this gap during their summer school. For the college of education, the opportunity for the preservice teachers to earn practicum hours in the summer, gain real-life experience, and help a local high school in the community were the major motivations. McGrath (2006) stated that when the scholarship of application is practiced in a setting outside of the university, it is called "outreach" (p. 4). The scholarship of application involves education and service for the public good (Bull, 1998). This summer school partnership was intended not only to enhance both the local high school and the preservice teachers, but it also provided a service to the local community as part of the university mission. Judging the scholarship of application is often based on the outcomes and impact made by this service (Bull, 1998).

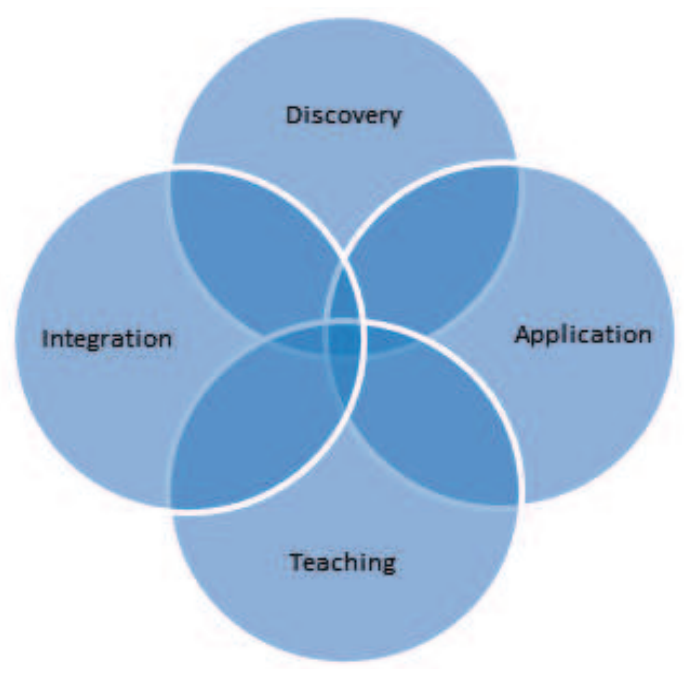

Figure 1. Boyer's Model Olof Scholarship, Showing the Four Proposed Forms of Scholarship.

The preservice teachers in this study were exposed to experiential learning, which Kolb (1984) described as "the process whereby knowledge is created through the transformation of experience" (p. 38). Kolb's experiential learning theory is represented by a four-stage learning cycle (see Figure 2). Effective learning progresses through these four stages. Learning can be defined as a process, not a product, that students construct in a sociocultural context (Boud, Cohen, \& Walker, 1993; Kolb \& Kolb, 2005). Kolb's experiential learning theory provides for interactive learning experiences that support the transformation through the four stages (Bolan, 2003; Kolb, 1984). For the preservice teachers in this study, the four stages were enacted in this summer practicum partnership. In stage one, their concrete experience was participating in the summer school partnership. Stage two consisted of writing their daily reflections while they observed and participated in teaching lessons and working with students. The preservice teachers moved to stage three by making assumptions about their learning at the conclusion of this summer partnership as they filled out the final survey identifying the benefits of the partnership to them and what improvements could be made. The move to stage four for the preservice teachers will hopefully be evident in their future 
Table 1. Demographic Data for Preservice Teachers

\begin{tabular}{|c|c|c|c|c|c|}
\hline $\begin{array}{c}\text { Preservice Teachers } \\
\text { (Students) }\end{array}$ & Gender & Ethnicity & Age & $\begin{array}{l}\text { Number of Practicum } \\
\text { Hours Completed }\end{array}$ & Year in College \\
\hline Student \#1 & Female & Caucasian & 21 & 161.50 & Senior \\
\hline Student \#2 & Male & Hispanic & 20 & 110.00 & Senior \\
\hline Student \#3 & Female & Hispanic & 19 & 99.25 & Junior \\
\hline Student \#4 & Female & Caucasian & 22 & 80.00 & Senior \\
\hline Student \#5 & Female & Caucasian & 21 & 74.00 & Senior \\
\hline Student \#6 & Female & Hispanic & 19 & 73.75 & Sophomore \\
\hline Student \#7 & Female & African-American & 23 & 72.00 & Senior \\
\hline Student \#8 & Male & Caucasian & 21 & 65.00 & Junior \\
\hline Student \#9 & Male & African-American & 21 & 61.50 & Junior \\
\hline Student \#10 & Female & Hispanic & 20 & 55.25 & Senior \\
\hline Student \#11 & Female & Hispanic & 21 & 50.25 & Senior \\
\hline Student \#12 & Male & African-American & 21 & 42.50 & Senior \\
\hline Student \#13 & Female & Hispanic & 23 & 35.50 & Senior \\
\hline Student \#14 & Female & Caucasian & 21 & 33.75 & Senior \\
\hline Student \#15 & Male & Caucasian & 20 & 33.00 & Junior \\
\hline Student \#16 & Female & Caucasian & 21 & 31.75 & Senior \\
\hline Student \#17 & Female & Hispanic & 19 & 31.75 & Sophomore \\
\hline Student \#18 & Female & Caucasian & 21 & 27.25 & Senior \\
\hline Student \#19 & Female & Caucasian & 19 & 27.00 & Sophomore \\
\hline Student \#20 & Female & Caucasian & 20 & 25.75 & Junior \\
\hline Student \#21 & Male & Asian & 21 & 23.50 & Junior \\
\hline Student \#22 & Female & Caucasian & 20 & 21.00 & Sophomore \\
\hline Student \#23 & Female & Caucasian & 19 & 20.25 & Sophomore \\
\hline Student \#24 & Female & Hispanic & 20 & 17.75 & Junior \\
\hline Student \#25 & Female & Hispanic & 22 & 17.00 & Junior \\
\hline Student \#26 & Female & Caucasian & 21 & 17.00 & Junior \\
\hline Student \#27 & Female & Caucasian & 20 & 16.75 & Sophomore \\
\hline Student \#28 & Female & Caucasian & 21 & 16.00 & Senior \\
\hline Student \#29 & Female & African-American & 19 & 14.00 & Sophomore \\
\hline Student \#30 & Female & Caucasian & 19 & 10.00 & Sophomore \\
\hline
\end{tabular}




\section{Active Concrete \\ t

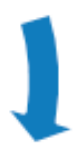 \\ Abstract \\ Reflective}

Figure 2. Image of Kolb's Learning Cycle, Adapted From Kolb (1984).

classes and student teaching as they apply what they learned in the summer partnership.

\section{METHODS}

Thirty-six preservice teachers participated in the summer school practicum with 23 high school teachers serving as their hosts. Thirty of those preservice teachers completed the summative survey (see Table 2), the data source used for this study. The preservice teachers completed 1,368 total practicum hours ranging from 10 to 161.5. (see Table 1).

Table 1 summarizes the demographic data for the preservice teachers who completed the survey. The preservice teachers are listed in order of the number of hours they completed with the highest number of hours first. There were 24 females (80\%) and 6 males $(20 \%)$. The ethnicity of the preservice teachers consisted of the following: 16 out of 30 or $53 \%$ were Caucasian; 9 out of 30 or $30 \%$ were Hispanic; 4 out of 30 or $13 \%$ were AfricanAmerican; and 1 out of 30 or $3 \%$ was Asian. There were 13 out of 30 or $43 \%$ seniors, 9 out of 30 or $30 \%$ were juniors, and 8 out of 30 or $27 \%$ were sophomores. The ages varied from 19-23 years old.

\section{Qualitative Data Analysis}

I used a grounded theory approach to analyze the qualitative data from this study. Data were analyzed using the process of open coding the raw data (Corbin \& Strauss, 2008). I started by breaking apart the data into categories based on their dimensions. Then I used axial coding to relate the concepts together. Open coding and axial coding go "hand in hand" according to Corbin and Strauss (2008, p. 198). The open coding came first as I examined the raw data with an open mind to find the underlying meaning from the text (Glaser \& Strauss, 1967). This is where I, as the researcher, tried to clarify what characteristics defined each category and which characteristics allowed for new categories or subcategories to be formed (Glaser \& Strauss, 1967). I followed this process of axial coding and relating the categories to the subcategories to eventually develop themes based on the data (Glaser \& Strauss, 1967; Miles \& Huberman, 1994).

Saturation of the data came after multiple attempts of defining and redefining the categories. Eventually three themes emerged for the benefits and three themes for the efficacy of the preservice teachers. The themes, theme-related components, and assertions presented in each analysis were organized into tables (see Table 3 and Table 4). Pseudonyms were used to keep the survey results anonymous. The units of data are numbered for each theme to show the strength of each theme based on the preservice teacher's surveys.

Table 2. Summer School Practicum Survey

\begin{tabular}{|l|l|}
\hline 1. & $\begin{array}{l}\text { What were the main benefits of the summer school partnership for } \\
\text { you personally? Explain. }\end{array}$ \\
\hline 2. & $\begin{array}{l}\text { What were some areas for improvement for the summer } \\
\text { partnership? Explain. }\end{array}$ \\
\hline 3. & $\begin{array}{l}\text { Did this experience impact your confidence (efficacy) as a future } \\
\text { teacher? If so, how? }\end{array}$ \\
\hline 4. & Other comments: \\
\hline
\end{tabular}

Note: This is a list of questions included on the survey to practicum students. Responses were open-ended.

Question \#1 from the final survey asked the preservice teachers what they viewed as the main benefits of the summer school practicum partnership. Table 3 summarizes the data in three themes. The major theme focused on real teaching experience, which improved their efficacy, as 54\% of the data from the preservice teachers related to this theme. Building relationships with the teachers and students was the second strongest theme with $26 \%$ of the data relating back to this theme. The third theme was about observing their mentor teachers, which $21 \%$ of the preservice teachers noted in this question.

The first theme that emerged was that the preservice teachers gained real teaching experience from planning and teaching lessons and practicing 
Table 3. Survey Themes for Benefits for Preservice Teachers

\begin{tabular}{|c|l|l|l|l|}
\hline Theme & \multicolumn{1}{|c|}{$\begin{array}{c}\text { Theme Related } \\
\text { Components }\end{array}$} & \multicolumn{1}{c|}{ Assertions } & \multicolumn{1}{c|}{$\begin{array}{c}\text { Units/ Chunks of Data } \\
\text { Collected }\end{array}$} & of Units per Theme \\
\hline Real teaching experience & $\begin{array}{l}\text { Planning/teaching lessons; } \\
\text { Practice with classroom } \\
\text { management; }\end{array}$ & $\begin{array}{l}\text { Preservice teachers } \\
\text { gained real experience } \\
\text { from planning, teaching, } \\
\text { and practicing classroom } \\
\text { management. }\end{array}$ & 31 & $54 \%$ \\
\hline $\begin{array}{c}\text { Relationships with students } \\
\text { and teachers }\end{array}$ & $\begin{array}{l}\text { Connecting/Relating with } \\
\text { high school students; } \\
\text { Connecting with mentor } \\
\text { teachers; }\end{array}$ & $\begin{array}{l}\text { Preservice teachers grew } \\
\text { in relating to high school } \\
\text { students and their mentors. }\end{array}$ & 15 & $26 \%$ \\
\hline $\begin{array}{l}\text { Observation of aspects of } \\
\text { teaching }\end{array}$ & $\begin{array}{l}\text { Learned from observing } \\
\text { teaching, planning, and } \\
\text { classroom management; } \\
\text { Observed mentors } \\
\text { interacting with students; }\end{array}$ & $\begin{array}{l}\text { Preservice teachers } \\
\text { improved from observing } \\
\text { real teaching and relating to } \\
\text { students. }\end{array}$ & 12 & $21 \%$ \\
\hline
\end{tabular}

classroom management with students from this summer practicum partnership. This was by far the strongest theme, as it was evident in 54\% of the comments about the benefits of the partnership. One preservice teacher stated the following about the main benefits of the partnership, "Perhaps the biggest benefit was getting more experience in the classroom" (Student \#2). Another pointed out the involvement during the summer program as compared to their normal practicum experiences by stating this, "I wasn't a passive observer like in my previous practicums. I became an integral part of the classroom" (Student \#3). In the area of classroom management, a preservice teacher noted, "I was able to experience with many different techniques for classroom management. I was able to finally practice all that I have been taught thus far in my courses" (Student \#6). When it came to lesson planning, one preservice teacher pointed out the main difference between being there daily in summer school versus during the fall or spring by stating,

\section{I think that a big benefit of the partnership} was that I was able to see how I would put together a unit. Since I was able to be in one classroom for a full semester worth of work it was easier to conceptualize how I would be able to work standards into lessons, whereas in the regular school year I am in and out of the practicum classes during different units. (Student \#10)

This first theme of real teaching experience due to actual planning, teaching, and using classroom management skills will definitely benefit the preservice teachers as they move closer to their student teaching.

The theme of relationships with students and teachers was the second strongest as it accounted for $34 \%$ of the comments from the preservice teachers about the benefits of the summer partnership. One preservice teacher pointed out that they had not completed a practicum at the high school level before and how this benefitted them by stating, "I got an inside look at how high school students interact with each other and how I should interact with them" (Student \#23). Another preservice teacher mentioned her favorite part of summer school this way,

What I loved most is that I got to be with the same students day-in and day-out and got to do a lot of interacting with them. I have never had much of an opportunity to work 
Table 4. Survey Themes for Efficacy of Preservice Teachers

\begin{tabular}{|c|l|l|l|l|}
\hline Theme & \multicolumn{1}{|c|}{ Theme Related Components } & \multicolumn{1}{|c|}{ Assertions } & $\begin{array}{l}\text { Units/ Chunks of Data } \\
\text { Collected }\end{array}$ & $\begin{array}{c}\text { \% of Units per } \\
\text { Theme }\end{array}$ \\
\hline Real teaching experience & $\begin{array}{l}\text { Planning/teaching lessons improved } \\
\text { efficacy; } \\
\text { Practice with classroom } \\
\text { management improved efficacy; }\end{array}$ & $\begin{array}{l}\text { Preservice teachers gained } \\
\text { efficacy from real teaching } \\
\text { experiences. }\end{array}$ & 27 & $54 \%$ \\
\hline $\begin{array}{c}\text { Relationships with students } \\
\text { and teachers }\end{array}$ & $\begin{array}{l}\text { Connecting/relating with high } \\
\text { school students; } \\
\text { Connecting with mentor teachers; }\end{array}$ & $\begin{array}{l}\text { Preservice teachers grew in } \\
\text { efficacy from relating to high } \\
\text { school students and their } \\
\text { mentors. }\end{array}$ & 17 & $34 \%$ \\
\hline $\begin{array}{c}\text { Observation of aspects of } \\
\text { teaching }\end{array}$ & $\begin{array}{l}\text { Learned from observing teaching, } \\
\text { planning, and classroom } \\
\text { management; Observed mentors } \\
\text { interacting with students; }\end{array}$ & $\begin{array}{l}\text { Preservice teachers improved } \\
\text { their efficacy from observing } \\
\text { real teaching. }\end{array}$ & 6 & $12 \%$ \\
\hline
\end{tabular}

on my skills with interacting with students. (Student \#5, final survey)

This preservice teacher pointed out the importance of collaborating with mentor teachers by stating, "I enjoyed the chance to collaborate with teachers more closely and better understand the role of a teacher" (Student \#10). Finally, a preservice teacher added this key point, "I was able to make connections with successful educators that can help me improve my teaching skills or give me more exposure to the classroom" (Student \#11). Building relationships with the high school students and their mentors positively impacted the preservice teachers in this partnership.

The third theme was observation of aspects of teaching, evident in $21 \%$ of the preservice teachers' surveys when asked about the main benefits of the partnership. A preservice teacher stated it this way, "I saw firsthand how my mentor teacher created lessons, how she adjusted the materials and the lessons throughout the day based on the students' response to the material, and how she graded" (Student \#3). Another preservice teacher stated, "A benefit was being able to witness a teacher in action and learn from that teacher and be able to help the teacher where needed" (Student \#20). Finally, a preservice teacher with more practicum experience at the elementary level stated, "I was able to see a high school classroom setting. I was very excited for this because I was able to discuss different teaching strategies with the teacher I was observing" (Student \#27). Observing mentor teachers had a positive impact on the preservice teachers that participated in this study.

Question \#3 asked if this experience impacted their confidence (efficacy) as a future teacher. Table 4 has the data summarized into three themes. The major theme again focused on real teaching experience, which improved their efficacy, as 54\% of the data from the preservice teacher related to this theme. Building relationships with the high school students and teachers was the second strongest theme with $34 \%$ of the data relating to this theme. The third theme was not as strong with $12 \%$ of the data relating to the theme of observing different aspects of teaching which improved the efficacy of the preservice teachers.

The first theme of real teaching experience was evident in the data. One preservice teacher stated the following, "I feel extremely confident in my ability to teach students and know they will be successful" (Student \#1). Another preservice teacher said it this way, "I think this experience actually boosted my confidence even more. I am far more comfortable teaching than I was before" (Student \#2). Another preservice teacher pointed out how the students saw her by saying, "I was more confident that I was seen as a teacher rather than a student. It was an experience that helped me to not be afraid to be part of the classroom in the future" (Student \#3). It 
is clear that the efficacy of the preservice teachers improved from many real-life teaching experiences during this summer practicum partnership.

The second theme of relationships with students and teachers was noted in $34 \%$ of the data as having an impact on the efficacy of the preservice teachers. One preservice teacher pointed out the students' reaction to his teaching this way, "Just coming to school and improving my skills truly boosted my confidence and my students expressed their gratitude towards me which also boosted my confidence" (Student \#2). Another preservice teacher liked her communication with her mentor teacher when she said, "I was able to ask my mentor teacher questions about certain situations in a more relaxed environment than during a regular school year" (Student \#4). A preservice teacher in an English classroom stated,

\section{I feel so much more confident about working with English Language Learners and students who struggle with English. We had a lot of students who struggled with writing and I got to grade a lot of work and go over my grading with my mentor teacher, which has boosted my confidence for grading students fairly and accurately. (Student \#5)}

Another preservice teacher mentioned the relationships' impact on her efficacy this way, "I learned that I can conquer the challenges even if they are small as looking for pencils or as significant as trying to help a group of 30 or more students to understand how to identify metaphors and similes" (Student \#6). The efficacy of the preservice teachers was clearly impacted by their relationships with their students and mentor teachers.

The third theme of observations of aspects of teaching accounted for $12 \%$ of the data that preservice teachers related to their efficacy. A preservice teacher pointed out how their efficacy improved from observing their mentor. He stated, "Yes this experience improved my confidence. I was able to see them go from learning the names on the first day all the way to a high level of trust at the end" (Student \#8). Another preservice teacher said,

Yes this experience helped my confidence. I liked being able to go into different classrooms this summer and view different teachers and students. I believe I gained a lot of knowledge and experience that will help me when I become a teacher. (Student \#19)

A preservice teacher pointed out what she learned from observing her mentor teacher when she stated, "My teacher helped me understand that the classroom does not need to be uptight, but can rather have a casual atmosphere that still welcomes learning" (Student \#13).

\section{REFLECTIVE CRITIQUE}

This study sought to answer two questions. The first question was: "What were the benefits of this summer practicum partnership?" The theme of real teaching experience was the most prevalent benefit as noted in $54 \%$ of the comments from the preservice teachers. They realized that this was an opportunity to gain experience in the classroom before they enter student teaching. The relationships these preservice teachers had with their students and their mentor teachers were also evident as it accounted for $26 \%$ of their feedback. The preservice teachers were also able to observe more teaching and this accounted for $21 \%$ of the feedback from the final survey. The comments from the preservice teachers about these three themes were very specific in that they benefitted strongly from this partnership.

Preservice teachers must understand the relationship between the ideas they are taught in classes and applying those ideas in a real setting, which this summer school partnership attempted to do (Hughes, 2006). It was an arranged application to enhance the development of their knowledge of the teaching profession. This partnership provided the preservice teachers the opportunity to learn experientially during a time when they are usually on vacation (Kolb, 1984). Gaining real teaching experience is crucial to the success of the preservice teachers in the college of education. The scholarship of application, as previously mentioned, seeks to close the gap between the university and real life (Boyer, 1997). Evidence appears to indicate that this summer practicum partnership did that to some degree for the preservice teachers based on their feedback.

The second question this study attempted to answer was: "How did this experience impact your 
efficacy as a future teacher?" The themes for this question mirrored the benefits, which enhances these results. Not only were the three themes consistent, the percentages were also very close. Again, there were $54 \%$ of the data that related back to this the theme of real teaching experience. This partnership allowed the opportunity for these preservice teachers to gain more confidence with more experience. Building relationships with their students and mentor teachers also positively impacted their efficacy as it was noted in $34 \%$ of the data. The observation of teaching was lower for building efficacy as it was evident in only $12 \%$ of the data.

Aydin and Woolfolk Hoy (2005) identified three key contributors to preservice teacher's selfefficacy for teaching. The first is the relationship between the preservice teacher and the mentor teacher. The second is the quality of the support from the mentor teacher. The third is the number of different practicum experiences. There is evidence of a correlation between the impacts of early practicum experiences on the self-efficacy of preservice teachers (Li \& Zhang, 2000). This summer practicum partnership provided the opportunity for the preservice teachers to build relationships with their mentor teachers, which were noted in the data. This summer experience also provided a different type of experience for the preservice teachers as it was during their vacation and the summer schedule was very different than the fall or spring schedule.

Overall, the preservice teachers felt they benefitted from this partnership and that it helped their own efficacy for teaching based on real experience that was gained. With the experience, the preservice teachers were able to practice connecting with students and learning from mentors. They had the opportunity to apply their learning from the university classroom to a reallife high school during summer school.

As a teacher-educator, I am excited whenever my preservice teachers are able to get real-life teaching experience at local high schools. The teaching of theory in the classroom should be linked to its application (Brunner, 1977). The gap that naturally exists from lessons or practice-teaching in front of their peers in the classroom is still not as valuable as real-life experience in a high school. I can attest to how this practical experience at a local high school has improved my preservice teachers' confidence and skill level and their classroom conversations about teaching.

I was surprised to read some of the comments of the preservice teachers as to why they enjoyed this experience more than their typical fall or spring practicums. The major reason was that the summer practicum provided more consistency with their mentor teacher and their students. The preservice teachers could work with the same students and teacher daily and make connections with them. The typical time for preservice teachers to fulfill practicum hours can vary depending on their school and work schedule. Practicums that are extensive and well thought out for preservice teachers can enhance their attitudes about teaching and give them more self-confidence and knowledge of the teaching profession (Thomson, Beacham, $\&$ Misulis, 1992). On the other hand, negative practicum experiences could promote undesirable attitudes about teaching and low self-efficacy about teaching for preservice teachers (Fallin \& Royse, 2000). The preservice teachers could have experienced positive boosts in their efficacy due to the fact that they were able to make choices about their schedule before summer school and even adjust it during the summer if they chose.

Another key point I noticed from the data was that the preservice teachers had never observed a classroom teacher from the beginning to the end of a semester. Even though summer school was only 19 days for four hours each day, a semester's worth of material was covered. This allowed the preservice teachers to observe the planning for a unit and how it connected with the following unit through a semester's worth of material. This is definitely not the case during the school year practicum experience. However, the long class times of four hours a day was also noted by some preservice teachers as a negative when it came to keeping the students engaged and motivated the entire time.

The level of involvement of the preservice teachers in the summer school classes varied based on the amount of practicum hours they logged and the comfort level of their mentor teacher from the high school. It seemed as though the preservice teachers that spent more hours/days of practicum in this high school gained the trust and respect of the practicum teachers and were allowed to be 
more involved in their classrooms (allowed to plan and teach lessons as opposed to just observing or working with individual students). The impact of spending more hours in practicum and being involved more in the actual teaching is something that will need to be examined more closely in future studies. It is vastly different for a preservice teacher who spent ten hours of practicum in this program to one who spent over 100 hours. Future studies might help to distinguish the impact of the amount of consistent daily time in the classroom versus just being there for a short time to fulfill a small number of practicum hours.

Overall, this partnership was successful in that it provided preservice teachers a different opportunity to work in advance on their practicum hours, but it also positively impacted their efficacy. The preservice teachers now have a new experience to draw upon in their future classes. They have been able to participate in summer school and gain valuable relationships along the way. Teacher educators should design the coursework and practicum experiences for preservice teachers to gradually increase their development so they will be more successful (Pendergast et al., 2011). Rohrkemper and Corno (1988) suggest that teacher education programs create practicums that allow preservice teachers to apply their learning and receive detailed feedback from their mentor. These experiences should be scaffolded in terms of difficulty, complexity, and level of frustration in order to build a positive sense of efficacy (Kent, Giles, \& Hibberts, 2013, p. 12). I urge other colleges of education to venture into similar summer school practicum partnerships not only as a means to provide more opportunities but a way to strengthen the experience of their preservice teachers. 


\section{REFERENCES}

Allen, J. M., \& Turner, D. (2012). School practitioners' and university staff members; perceptions of the pre-service teacher education practicum: A comparative study. Paper presented at Joint AARE APERA International Conference, Sydney.

Amrein-Beardsley, A., \& Barnett, J. H. (2012). It might just take a partnership. Issues in Teacher Education, 21(2), 103-124.

Anderson, R., \& Green, M., \& Loewen, P. (1988). Relationships among teachers' and students' thinking skills, sense of efficacy, and student achievement. Alberta Journal of Educational Research, 34(2), 148-165.

Ashton, P. (1984). Teacher efficacy: A motivational paradigm for effective teacher education. Journal of Teacher Education, 35(5), 287-232. doi:10.1177/002248718403500507

Aydin, Y. C., \& Woolfolk Hoy, A. (2005). What predicts student teacher self-efficacy? Academic Exchange Quarterly, 9(4), 123-127.

Ball, D., \& Cohen, D. (1999). Developing practice, developing practitioners: Toward a practice-based theory of professional education. In L. Darling-Hammond and G. Sykes (Eds.), Teaching as the learning profession: Handbook of policy and practice (pp. 3-32). San Francisco, CA: Jossey-Bass.

Bandura, A. (1982). Self-efficacy mechanism in human agency. American Psychologist, 37(2), 122. doi:10.1037/0003066X.37.2.122

Bandura, A. (1986). Social foundations of thought and action: $A$ social cognitive theory. New York, NY: Prentice-Hall, Inc.

Bandura, A. (1993). Perceived self-efficacy in cognitive development and functioning. Educational Psychologist, 28(2), 117-148.doi:10.1207/s15326985ep2802_3

Bandura, A. (1997). Editorial. American Journal of Health Promotion, 12(1), 8-10.

Bolan, C. (2003). Incorporating experiential learning theory into the instructional design of online courses. Nurse Educator, 28(1), 10-14. doi:10.1097/00006223-200301000-00006

Boud, D., Cohen, R., \& Walker, D. (1993). Introduction: Understanding learning from experience. In D. Boud, R. Cohen, \& D. Walker (Eds.), Using experience for learning (pp. 1-18). Buckingham, UK: Society for Higher Education and Open University Press.

Bowman, C., \& McCormick, S. (2000). Comparison of peer coaching versus traditional supervision effects. Journal of Educational Research, 93(4), 256-261. doi:10.1080/00220670009598714
Boyer, E. L. (1990). Scholarship reconsidered: Priorities of the professoriate. Princeton, NJ: The Carnegie Foundation for the Advancement of Teaching.

Boyer, E. L. (1997). Scholarship reconsidered: Priorities of the professoriate. San Francisco, CA: Jossey-Bass.

Brunner, J. (1977). The process of education. Cambridge, MA: Harvard University Press.

Bull, N. H. (1998). Defining scholarship for the University of Connecticut Cooperative Extension System. Storrs, CT: University of Connecticut Cooperative Extension System.

Butcher, J., Bezzina, M., \& Moran, W. (2011). Transformational partnerships: A new agenda for higher education. Innovative Higher Education, 36(1), 29-40. doi:10.1007/s10755-0109155-7

Byrne, J. V. (1998). Outreach, engagement, and the changing culture of the university. Journal of Public Service and Outreach, 3(2), 3-8.

Capa Aydin, Y., \& Loadman, W. E. (2006). Sources of first-year teachers' sense of efficacy. In Proceedings of the Fourth International Biennial SELF Research Conference: Selfconcept, motivation, social and personal identity for the 21st century: Ann Arbor, US, 23rd - 26th [July], 2006 (pp. 43-47). Bankstown, N.S.W.: University of Western Sydney.

Caprano, M. M., Capraro, R. M., \& Helfeldt, J. (2010). Do differing types of field experiences make a difference in teacher candidates' perceived level of competence? Teacher Education Quarterly, 37(1), 131-154. doi:10.2307/23479302

Chan, D. W. (2008). General, collective, and domain-specific teacher self-efficacy among Chinese prospective and in-service teachers in Hong Kong. Teaching and Teacher Education, 24(4), 1057-1069. doi:10.1016/j.tate.2007.11.010

Chassels, C., \& Melville, W. (2009). Collaborative, reflective, and iterative Japanese lesson study in an initial teacher education program: Benefits and challenges. Canadian Journal of Education, 32(4), 734-763.

Corbin. J., \& Strauss, A. (2008). Basics of qualitative research (3rd ed.). Los Angeles, CA: Sage.

Darling-Hammond, L. (2006). Constructing 21st century teacher education. Journal of Teacher Education, 57(3), 300-314. doi:10.1177/0022487105285962

Darling-Hammond, L. (2007). Race, inequality and educational accountability: The irony of 'No Child Left Behind.' Race Ethnicity and Education, 10(3), 245-260. doi:10.1080/13613320701503207 
Darling-Hammond, L. (2009). Recognizing and enhancing teacher effectiveness. The International Journal of Educational and Psychological Assessment, 3, 1-24.

Darling-Hammond, L., \& Hammerness, K. (2005). The design of teacher education programs. In L. Darling-Hammond \& J. Bransformd (Eds.), Preparing teachers for a changing world: What teachers should learn and be able to do (pp. 390-441). San Francisco, CA: Jossey-Bass.

Darling-Hammond, L., Jaquith, A., \& Hamilton, M. (2012). Creating a comprehensive system for evaluating and supporting effective teaching. Stanford, CA: Stanford Center for Opportunity Policy in Education (SCOPE).

Duncan-Andrade, J. M. R. (2011). The principal facts: New directions for teacher education. In A. F. Ball \& C. A. Tyson (Eds.), Studying diversity in teacher education (pp. 309-326). Lanham, MD: Rowman \& Littlefield Publishers.

Fallin, J., \& Royse, D. (2000). Student teaching: the keystone experience. Music Educators Journal, 87(3), 19-22. doi:10.2307/3399658

Flores, I. M. (2015). Developing preservice teachers' selfefficacy through field-based science teaching practice with elementary students. Research in Higher Education Journal, $27,1$.

Freeman, G. G. (2009-2010). Strategies for successful early field experiences in a teacher education program. SRATE Journal, 19(1), 15-21.

Ganesh, B., \& Matteson, S. M. (2010). The benefits of reteaching lessons in preservice methods classes. Action in Teacher Education, 32(4), 52-60. doi:10.1080/01626620.2010.549718

Gencer, A. S., \& Cakiroglu, J. (2007). Turkish preservice science teachers' efficacy beliefs regarding science teaching and their beliefs about classroom management. Teaching and Teacher Education, 23(5), 664-675. doi:10.1016/j. tate.2005.09.013

Glaser, B., \& Strauss, A. (1967). The discovery of grounded theory. Chicago, IL: Aldine.

Gordon, C., \& Debus, R. (2002). Developing deep learning approaches and personal teaching efficacy within a preservice teacher education context. British Journal of Educational Psychology, 72(4), 483-511. doi:10.1348/00070990260377488

Grossman, P., Compton, C., Igra, D., Ronfeldt, M., Shahan, E., \& Williamson, P. (2009). Teaching practice: A crossprofessional perspective. Teachers College Record, 111(9), 2055-2100.
Hardman, M. (2009). Redesigning the preparation of teachers within the framework of an integrated program model. Teaching and Teacher Education, 25(4), 583-587. doi:10.1016/j.tate.2009.02.005

Hiebert, J., Morris, A., Berk, D., \& Jansen, A. (2007). Preparing teachers to learn from teaching. Journal of Teacher Education, 58(1), 47-61. doi:10.1177/0022487106295726

Hoy, A. W. (2000). Changes in teacher efficacy during the early years of teaching. Presented at Annual Meeting of the American Educational Research Association, New Orleans, LA, April 28, 2000.

Hoy, A. W., \& Spero, R. B. (2005). Changes in teacher efficacy during the early years of teaching: A comparison of four measures. Teaching and Teacher Education, 21(4), 343-356doi:10.1016/j.tate.2005.01.007

Hughes, J. A. (2006). Bridging the theory-practice divide: A creative approach to effective teacher preparation. Journal of Scholarship of Teaching and Learning, 6(1), 110-117.

Kennedy, M. (1999). The role of preservice teacher education. In L. Darling-Hammond \& G. Sykes (Eds.), Teaching as the learning profession: Handbook of policy and practice (pp. 54-85). San Francisco, CA: Jossey-Bass.

Kent, A. M., Giles, R. M., \& Hibberts, M. (2013). Preparing elementary educators to teach reading: An exploratory study of preservice teachers' evolving sense of reading efficacy. International Journal for the Scholarship of Teaching and Learning, 7(2), 23.

Kolb, A., \& Kolb D. A. (2005). Learning styles and learning spaces: Enhancing experiential learning in higher education. Academy of Management Learning and Education, 4(2), 193-212.

Kolb, D. A. (1984). Experiential learning: Experience as the source of learning and development (Vol. 1). Englewood Cliffs, $\mathrm{NJ}$ : Prentice-Hall.

Levine, A. (2006). Educating school teachers. Washington, D.C.: Education Schools Project.

Li, X., \& Zhang, M. (2000). Effects of early field experiences on preservice teachers' efficacy beliefs: A pilot study. Paper presented at the Annual Meeting of the American Educational Research Association, New Orleans, LA, April 24-28, 2000.

Lin, H. L., Gorrell, J., \& Taylor, J. (2002). Influence of culture and education on US and Taiwan preservice teachers' efficacy beliefs. The Journal of Educational Research, 96(1), 37-46. doi:10.1080/00220670209598789 
Louden, W., \& Rohl, M. (2006). "Too many theories and not enough instruction": Perceptions of preservice teacher preparation for literacy teaching in Australian schools. Literacy, 40(2), 66-78. doi:10.1111/j.1467-9345.2006.00440.x

Lynton, E. A. (12016). Ensuring the quality of outreach: The critical role of evaluating individual and collective initiatives and performance. Journal of Higher Education Outreach and Engagement, 20(1), 35-44.

McDonald, D., \& Kahn, M. (2014). So, you think you can teach?Reflection processes that support pre-service teachers' readiness for field experiences. International Journal for the Scholarship of Teaching and Learning, 8(2). doi:10.20429/ ijsotl.2014.080218

McGrath, D. M. (2006). The scholarship of application. Journal of Extension, 44(2).

Midgley, C., Feldlaufer, H., \& Eccles, J. S. (1989). Change in teacher efficacy and student self-and task-related beliefs in mathematics during the transition to junior high school. Journal of Educational Psychology, 81(2), 247. doi:10.1037/0022-0663.81.2.247

Miles, M. B., \& Huberman, A. M. (1994). Qualitative data analysis (2nd ed.). Thousand Oaks, CA: Sage.

Moore, W., \& Esselman, M. (1992). Teacher efficacy, power, school climate and achievement: A desegregating district's experience. Presented at Annual Meeting of the American Educational Research Association, San Francisco, CA, April 20-24 1992.

Morris, A., Hiebert, J., \& Spitzer, S. (2009). Mathematical knowledge for teaching in planning and evaluating instruction: What can preservice teachers learn? Journal for Research in Mathematics Education, 40(5), 491-529.

Moseley, C., Reinke, K., \& Bookout, V. (2003). The effect of teaching outdoor environmental education on elementary preservice teachers' self-efficacy. Journal of Elementary Science Education, 1-14. doi:10.1007/BF03174740

Mulholland, J., \& Wallace, J. (2001). Teacher induction and elementary science teaching: Enhancing self-efficacy. Teaching and Teacher Education, 17(2), 243-261. doi:10.1016/ S0742-051X(00)00054-8

Munby, H., Russell, T., \& Martin, A. K. (2001). Teachers' knowledge and how it develops. In V. Richardson (Ed), Handbook of research on teaching (4th ed.)(pp. 877-905). Washington D.C.: American Educational Research Association.

National Council for Accreditation of Teacher Education (NCATE). (2014). What makes a teacher effective? Retrieved from http:// www.ncate.org/LinkClick.aspx?fileticket=JFRrmWqa1jU\%3d\& tabid $=361$
Oh, S. (2011). Preservice teachers' sense of efficacy and its sources. Psychology, 2(3), 235-240. doi:10.4236/ psych.2011.23037

Pendergast, D., Garvis, S., \& Keogh, J. (2011). Pre-service studentteacher self-efficacy beliefs: An insight into the making of teachers. Australian Journal of Teacher Education, 36(12), 46-57. doi:10.14221/ajte.2011v36n12.6

Rohrkemper, M., \& Corno, L. (1988). Success and failure on classroom tasks: Adaptive learning and classroom teaching. The Elementary School Journal, 88(3), 297-312. doi:10.1086/461540

Ross, J. A. (1992). Teacher efficacy and the effects of coaching on student achievement. Canadian Journal of Education, 17(1), 51-65. doi:10.2307/1495395

Sachs, J. (1999). Using teacher research as a basis for professional renewal. Journal of Inservice Education, 25(1), 39-53. doi:10.1080/13674589900200072

Schön, D. A. (1987). Educating the reflective practitioner. San Francisco, CA: Jossey Bass.

Schön, L. (1995). Development of the relationship triangle fathermother-child: Triangulation as a lifelong process. Berlin, Germany: Kohlhammer.

Stephens, D., \& Boldt, G. (2004). School/university partnerships: Rhetoric, reality, and intimacy. Phi Delta Kappan, 85(9), 703-708. doi:10.1177/003172170408500912

Thomson, W. S., Beacham, B. G., \& Misulis, K. E. (1992). A university and public school collaborative approach to preparing elementary teachers. The Teacher Educator, 28(2), 46-52. doi:10.1080/08878739209555028

Tobin, K., Roth, W., \& Zimmerman, A. (2001). Learning to teach science in urban schools. Journal of Research in Science Teaching, 38(8), 941-964. doi:10.1002/tea.1040

Tschannen-Moran, M., \& Hoy, A. W. (2007). The differential antecedents of self-efficacy beliefs of novice and experienced teachers. Teaching and Teacher Education, 23(6), 944-956. doi:10.1016/j.tate.2006.05.003

Wagler, R. (2011). Out in the field: Assessing the impact of vicarious experiences on preservice elementary science teaching efficacy. Electronic Journal of Science Education, 15(2).

Webb, E., Ashton, C. H., Kelly, P., \& Kamali, F. (1996). Alcohol and drug use in UK university students. The Lancet, 348(9032), 922-925.

Wenner, G. (2001). Science and mathematics efficacy beliefs held by practicing and prospective teachers: A 5-year perspective. Journal of Science Education and Technology, 10(2), 181-187. doi:10.1023/A:1009425331964 
Woolfolk, A. E., \& Hoy, W. K. (1990). Prospective teachers' sense of efficacy and beliefs about control. Journal of Educational Psychology, 82(1), 81-91. doi:10.1037/0022-0663.82.1.81

Yeung, K. W., \& Watkins, D. (2000). Hong Kong student teachers' personal construction of teaching efficacy. Educational Psychology, 20(2), 213-235. doi:10.1080/713663713

Yılmaz, H., \& Çavaş, P. H. (2008). The effect of the teaching practice on pre-service elementary teachers' science teaching efficacy and classroom management beliefs. Eurasia Journal of Mathematics, Science \& Technology Education, 4(1), 45-54. doi:10.12973/ejmste/75305 